\title{
DETERMINATION OF POTASSIUM DESORPTION INDEX OF SOME SOIL ORDERS IN KURDISTAN REGION - IRAQ
}

Haifa S. Yaseen Akrawi

Akram O. Esmail

College of Agriculture, University of Salahaddin - Erbil/ Iraqi Kurdistan Region akrawi72@yahoo.com arez96y@yahoo.com

\section{ABESTRACT}

This research was conducted to study the K- kinetics' adsorptiondesorption phenomena in predominant soil orders (Mollisols, Entisols, Vertisols, Aridisols, and Inceptisols) of Kurdistan region- Iraq, Soil samples were taken from sixteen different locations at depth $(0-30 \mathrm{~cm})$ selected according to the variation in their soils order, physical, and chemical properties. The study included Kinetics of potassium adsorption and desorption were determined depending on miscible displacement techniques using $0.001 M \mathrm{KCl}$ and $0.01 \mathrm{M} \mathrm{CaCl}_{2}$ respectively, by applying First order equation, and determine the desorption index (DI) depended on the ratio of potassium desorption and adsorption isotherm slopes: The main results refer, the adsorption capacity ranged from 2.52 to $4.46 \mathrm{cmol}_{\mathrm{c}} \mathrm{kg}^{-1}$ the lowest value was recorded in Inceptisols, while the highest value in recoded in Mollisols, but the desorption capacity was ranged from 1.11 to 2.67 cmolc $\mathrm{kg}-1$ with the mean value $1.99 \mathrm{cmol}_{\mathrm{c}} \mathrm{kg}^{-1}$, the lowest value was recorded in Inceptisols while the highest value was recorded in Mollisols. Cumulative adsorption and desorption of potassium increased with increasing the time for all samples. The value of desorption index (DI) was ranged from 0.26 to 0.58 . The low value of DI indicated increased hysteresis and increase difficulty of the sorbed $\mathrm{K}^{+}$to desorb from soil surfaces.

Key words: Adsorption, Desorption, desorption index

Received: 19/2/2012 Accepted: 10/9/2012

\section{INTRODUCTION}

Potassium is the seventh most common element in the Earth's crust and in the upper $20 \mathrm{~cm}$ of the soil profile, the average potassium content of earth crust $23 \mathrm{~g} \mathrm{~K}^{-1}$ (Sparks, 2000). Fixation and release of $\mathrm{K}^{+}$depends on the level of $\mathrm{K}^{+}$in the soil solution, the type of clay minerals exists in the soil and wetting and drying (Dhaliwal et al., 2006). The kind and the amount of clay minerals control the distribution of $\mathrm{K}^{+}$ among soil solution $\mathrm{K}^{+}$, exchangeable $\mathrm{K}^{+}$, and fixed- $\mathrm{K}^{+}$fractions. The nature of soil mineralogy also influences plant mobilization of soil reserve $\mathrm{K}^{+}$greatly compared with the amount of clay and silt fractions (Conti et al. 2001). The clay type is considered to be the most dominant factor affecting $\mathrm{K}^{+}$fixation. The fixed power of the 2:1 clay minerals are Vermiculite > Illite > Smectite (Goli-Kalanpa et al., 2008). Also it has been reported that drying and wetting decrease the availability of $\mathrm{K}^{+}$for plants because of the increase in $\mathrm{K}^{+}$fixation capacity of clay mineral (Sparks, 2001). The most important aspect of $\mathrm{K}^{+}$transformation in soil is the rate at which the non-exchangeable

Apart of Ph.D Thesis. 
portion is released to exchangeable and soluble forms. The kinetic and equilibrium reaction between the forms of $\mathrm{K}^{+}$in soil depends mainly on two processes namely addition and removal of $\mathrm{K}^{+}$from soils. The addition of $\mathrm{K}^{+}$can be divided into two main parts, the $\mathrm{K}^{+}$release from soil minerals and organic matter and the fertilization of soil; on the other hand the removal of $\mathrm{K}^{+}$from soils can be related to the leaching and $\mathrm{K}^{+}$uptake by plants and microbes (Wada and Kakuto, 1993). Numerous studies have been conducted to characterize specific pools and rate coefficient such as for adsorption - desorption and fixation - release kinetics. Several models and techniques have been employed in the study of desorption and release kinetic of $\mathrm{K}^{+}$, include batch and miscible displacement techniques (Sparks et al., 1980), $\mathrm{H}^{+}$resin (Martine and Sparks, 1983), $\mathrm{Ca}^{2+}$ - resin (Goulding, 1984), and Na TPB have been used as a sink for $\mathrm{K}^{+}$(Cox and Joern, 1997). Kinetic is general term refers to time - dependent phenomena. Chemical kinetics can be defined as the study of the rate of chemical reaction and molecular processes by which reaction occurs where transport is not limiting (Gardiner, 1969)

Improved farming practices and the use of high yielding crop varieties, along with fertilizer nitrogen $\mathrm{N}$ application, increased crop production in Kurdistan, at the same time soils become more deficient in plant nutrients. Increase in crop production with increasing use of $\mathrm{N}$ and $\mathrm{P}$ fertilizers results the $\mathrm{K}$-deficiency. Inadequate $\mathrm{K}^{+}$ application along with remove of straw from wheat fields has caused increase in $\mathrm{K}$ deficiency and significant responses of crop to $\mathrm{K}^{+}$fertilizer application The rate and quantity of the release of non- exchangeable to exchangeable and soluble $\mathrm{K}^{+}$primarily depends on the level of $\mathrm{K}^{+}$in the soil solution, the exchangeable $\mathrm{K}^{+}$of Kurdistan soil is high 0.64 to $1.99 \mathrm{cmol}_{\mathrm{c}} \mathrm{kg}^{-1}$, especially in the cultivated layer ( Al- Zubaidi 2003).

Further investigation on $\mathrm{K}^{+}$fixation in Kurdistan soil showed that the soils have a high fixation capacity, 42 to $58 \%$ of the added $\mathrm{K}^{+}$, X-ray diffraction showed that the high K-fixation capacity was mostly attributed to vermiculite mineral (Al- Zubaidi, 2003). Al- Obaidi and Hassan (2008) studied the kinetics of $\mathrm{K}^{+}$adsorption in some rain fed soil of northern Iraq (Kurdistan region) by using miscible displacement method they showed that the adsorption process passed throw two stages, first one was rapid adsorption followed by slow adsorption, overall rate coefficient of adsorption ranged from $23-190 * 10^{-4} \mathrm{~min}^{-1}$, and they observed that the coefficient of $\mathrm{K}^{+}$ adsorption in fine texture was more than in coarse texture. Mehmedany (1999), Mam Rasul (2008) recorded that the first order equation was the best equation to describe the reaction rate of $\mathrm{K}^{+}$desorption from Duhok and Sulaimani governorate (Kurdistan region), since there was little or no studies at Kurdistan region included studing of $\mathrm{K}^{+}$ desorption index for the main soil orders for this reason this study was done to determine potassium desorption index of some soil orders at Kurdistan region, Iraq.

\section{MATERIAL AND METHOD}

Sixteen soil samples belonging to agriculturally important soils were taken from 5 soil order s (Mollisols, Vertisols, Aridisols, Inceptisols, and Entsols) at Kurdistan region (Figure 1). 


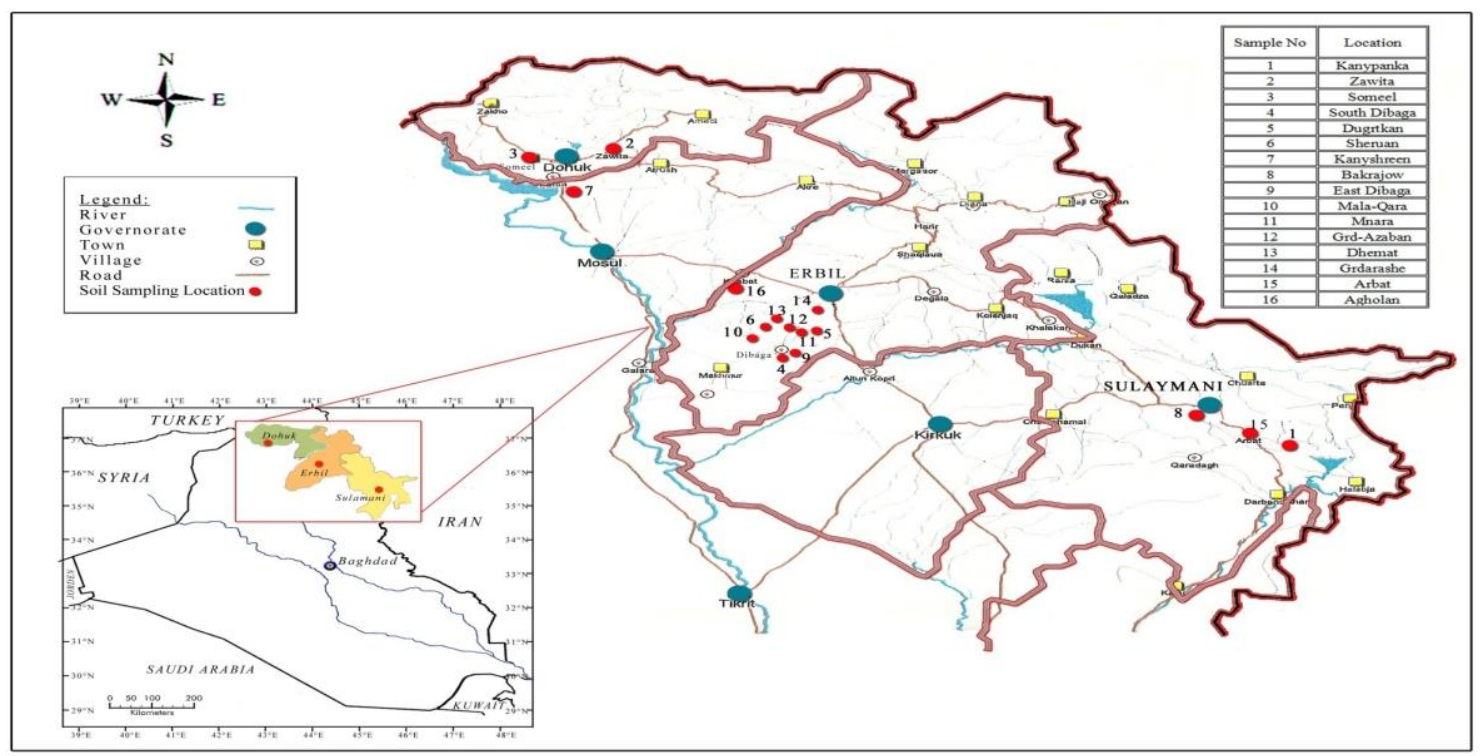

Figure (1): Samples location from Iraqi Kurdistan region

The soil samples were air dried and ground to pass through a $2 \mathrm{~mm}$ sieve for some chemical and physical analysis (Table, 1). The soil particle size distribution was determined using pipette method (Klute, 1986); Soil $\mathrm{pH}$ of the saturated extract was measured with $\mathrm{pH}$-meter, organic matter was determined according to Walkly and Black method described by (Jackson,1973); Electrical conductivity (EC) for saturation extract was measured by using EC-meter (Hesse, 1971); Total equivalent calcium carbonate $\left(\mathrm{CaCO}_{3}\right)$ was determined using $1 M \mathrm{HCl}$ followed by back titration with $1 M$ $\mathrm{NaOH}$ using phenolphthalein indicator as described by ( Richards, 1954); Active calcium carbonate was determined procedure as $2.5 \mathrm{~g}$ of soil samples were shaken with $(0.2 M)$ ammonium oxalate to precipitate calcium oxalate and the excess of ammonium oxalate was determined by titration with potassium permanganate according to (Kozhekov and Yakovoleva, 1977); cation exchange capacity CEC was determined by saturating the soils with $1 M \mathrm{NaOAc}$ at $\mathrm{pH} 8.2$ and washed with ethanol (exchangeable $\mathrm{Na}$ was replaced with $1 M \mathrm{NH} 4 \mathrm{OAc}$ ) then $\mathrm{Na}$ concentration was analyzed by flame photometer (Hesse, 1971 ). The soils were classified according to United Stuff Department of Agriculture (USDA) soil Taxonomy (Soil Survey Stuff, 1999).

\section{Forms of Potassium:-}

1-Soluble Potassium was determined in saturated soil paste extract by using flame photometer according to Rowell (1996).

2-Exchangeable Potassium $\left(\mathrm{K}_{\mathrm{ex}}\right)$ was extracted from soil by two different methods including $1 M \mathrm{HN}_{4} \mathrm{OAc}$ at $\mathrm{pH} 8.1$, and $0.5 M \mathrm{CaCl}_{2}$ solution (Pratt, 1982).

3- Non-exchangeable potassium $\left(\mathrm{K}_{\text {non-ex }}\right) 0.5 \mathrm{~g}$ of soil was boiled in $50 \mathrm{ml}$ of $1 \mathrm{M}$ $\mathrm{HNO}_{3}$ solution for 20 min according to Page et al., (1982), and then $\mathrm{K}_{\text {non-ex }}$ was calculated from the difference between the amount of $\mathrm{K}^{+}$which was extracted by boiling $\mathrm{HNO}_{3}$ and the amount which was extracted by $0.5 \mathrm{M} \mathrm{CaCl}_{2}$.

Potassium adsorption using miscible displacement technique:- The miscible displacement technique used as mentioned by Sparks and Rechcigl (1982), the stages of miscible displacement technique can be summarized as follow: Calcium saturation: A duplicate $1.00 \mathrm{~g}$ of soil sample in to $47 \mathrm{~mm}$ Nucleopore filter- column. The sample was saturated with $0.5 \mathrm{M} \mathrm{CaCl}_{2}$ solution at rate of $1 \mathrm{ml} \mathrm{min}^{-1}$ until equilibrium. Was reached later on (to remove $\mathrm{K}_{\mathrm{ex}}$ from surface of the soil samples). 
-Adsorption: The Ca saturated soil was leached with the $0.001 M \mathrm{KCl}$ solution supplied at steady rate to renew the 'soil solution' and to assess $\mathrm{K}^{+}$adsorption at constant $\mathrm{K}^{+}$concentration in the 'soil solution'. The solution was leached at a rate of 1 $\mathrm{ml} \mathrm{min}^{-1}$ for each $10 \mathrm{~min}$ until the concentration of the leached equaled to the concentration of initial $\mathrm{K}^{+}$solution. The difference between initial and final $\mathrm{K}^{+}$ concentration was assumed to be the amount of $\mathrm{K}^{+}$adsorbed by the soil.

Table (1): Some physical and chemical properties of the studied soil

\begin{tabular}{|c|c|c|c|c|c|c|c|c|c|}
\hline \multirow{3}{*}{ 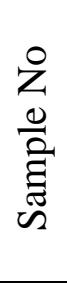 } & \multirow{3}{*}{ 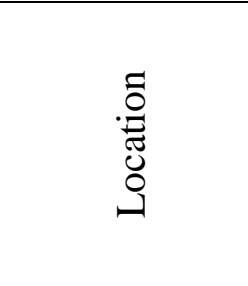 } & \multirow{3}{*}{$\begin{array}{l}\frac{\infty}{0} \\
\frac{0}{0} \\
\frac{0}{0} \\
\dot{0}\end{array}$} & \multirow{3}{*}{ 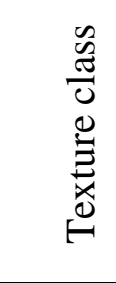 } & \multirow{3}{*}{ 垔 } & \multirow{3}{*}{$\begin{array}{l}1 \Xi \\
\tilde{S} \\
0 \\
0 \\
0\end{array}$} & \multirow{3}{*}{ 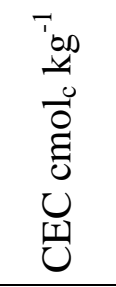 } & \multirow{3}{*}{$\sum_{0}^{T} \frac{100}{0,0}$} & \multirow{2}{*}{\multicolumn{2}{|c|}{$\begin{array}{c}\mathrm{CaCO}_{3} \\
\begin{array}{c}\text { Equivalents } \\
\mathrm{g} \mathrm{kg}^{-1}\end{array}\end{array}$}} \\
\hline & & & & & & & & & \\
\hline & & & & & & & & Total & Active \\
\hline 1 & Kanypanka & Mollisols & $\mathrm{SiC}$ & 7.10 & 0.46 & 48.69 & 29.00 & 115.50 & 82.50 \\
\hline 2 & Zawita & Mollisols & $\mathrm{SiCL}$ & 6.90 & 0.62 & 63.40 & 89.80 & 165.00 & 31.00 \\
\hline 3 & Someel & Vertisols & $\mathrm{SiCL}$ & 7.32 & 0.27 & 37.20 & 19.20 & 297.50 & 110.00 \\
\hline 4 & South Dibaga & Vertisols & $\mathrm{SiCL}$ & 7.42 & 0.46 & 52.04 & 20.50 & 435.00 & 84.00 \\
\hline 5 & Dugrtkan & Vertisols & SiCL & 7.40 & 0.44 & 43.74 & 23.10 & 375.00 & 147.00 \\
\hline 6 & Sheruan & Vertisols & SiCL & 7.15 & 0.36 & 40.00 & 26.70 & 234.00 & 78.00 \\
\hline 7 & Kanyshreen & Aridisols & $\mathrm{SiC}$ & 7.13 & 0.32 & 39.05 & 17.40 & 405.00 & 127.00 \\
\hline 8 & Bakrajow & Inceptisols & SiCL & 7.50 & 0.44 & 25.13 & 31.00 & 177.00 & 86.00 \\
\hline 9 & Este Dibaga & Inceptisols & SiCL & 7.12 & 0.52 & 36.94 & 19.90 & 345.00 & 74.50 \\
\hline 10 & Mala Qara & Inceptisols & $\mathrm{SiCL}$ & 7.16 & 0.52 & 46.48 & 23.20 & 199.00 & 55.00 \\
\hline 11 & Mnara & Inceptisols & $\mathrm{SiC}$ & 7.34 & 0.44 & 42.20 & 29.20 & 362.00 & 98.00 \\
\hline 12 & Grd Azaban & Inceptisols & $\mathrm{SiL}$ & 7.59 & 0.34 & 22.90 & 21.20 & 288.00 & 110.00 \\
\hline 13 & Dhemat & Inceptisols & $\mathrm{SiCL}$ & 7.31 & 0.48 & 37.70 & 20.90 & 342.50 & 86.00 \\
\hline 14 & Grd arash & Inceptisols & $\mathrm{SiCL}$ & 7.22 & 0.26 & 31.42 & 20.10 & 300.00 & 85.00 \\
\hline 15 & Arbat & Entisols & $\mathrm{SiCL}$ & 7.51 & 0.37 & 30.82 & 24.80 & 265.00 & 78.00 \\
\hline 16 & Agholan & Entisols & $\mathrm{CL}$ & 7.31 & 0.22 & 41.37 & 16.20 & 360.00 & 81.00 \\
\hline & Average & & & 7.28 & 0.41 & 39.94 & 27.01 & 291.59 & 88.31 \\
\hline
\end{tabular}

-Desorption: The desorption of $\mathrm{K}^{+}$was then initiated using $0.01 M \mathrm{CaCl}_{2}$ the solution of $\mathrm{CaCl}_{2}$ were passed through the soil at rate $1 \mathrm{ml} \mathrm{min}^{-1}$ for $10 \mathrm{~min}$ until no $\mathrm{K}^{+}$ appeared in the leached. The quantity of $\mathrm{K}^{+}$in solution for both the adsorption and desorption studies was measured by flame photometer.

$\mathrm{K}$ - adsorption-desorption values were calculated according first equation:-

First order models for adsorption: $\log \left(1-\mathrm{C}_{\mathrm{t}} / \mathrm{C}_{\mathrm{o}}\right)=-\mathrm{K}_{\mathrm{a}} \mathrm{t}$

The desorption rate coefficient (slop of the linear curve) of $\mathrm{K}$ was calculated according to first order equation as:

$\log \left(\mathrm{C}_{\mathrm{t}} / \mathrm{C}_{\mathrm{o}}\right)=\mathrm{a}-\mathrm{K}_{\mathrm{d}} \mathrm{t}$

Where: $\mathrm{C}_{\mathrm{t}}$ : amount of cumulative potassium adsorption or desorption, $\mathrm{C}_{0}$ : maximum potassium adsorption or desorption, $\mathrm{t}$ : time of adsorption or desorption, $\mathrm{K}_{\mathrm{d}}$ : Desorption isotherm slope, and $\mathrm{K}_{\mathrm{a}}$ : Adsorption isotherm slope.

\section{Desorption Index}

The desorption index was calculated using the following formula according to

Marazadori et al., (1991): $\quad \mathrm{DI}=\left(\mathrm{K}_{\mathrm{d}} / \mathrm{K}_{\mathrm{a}}\right) 100 \quad \ldots \ldots$. (3

Where: DI : Desorption index. 


\section{RESULTS AND DISCUSSION}

Adsorption Capacity:Figure (2) indicates to adsorption capacity (AC) of the studied soils, the values of AC were ranged from 2.52 to $4.46 \mathrm{cmol}_{\mathrm{c}} \mathrm{kg}^{-1}$, the highest value was recorded from sample No 2 (mollisols), while the lowest value was recorded from sample No 11 (Inceptisols). The variation of K-adsorption in the studied soils reflect the differences in chemical and mineralogical properties of studied soils, as a result of $\mathrm{X}$-ray diffraction the Smectite is a dominate mineral in Mollisols sample No 1 and 2 its could increase $\mathrm{K}^{+}$fixation, while the chlorite is a major mineral in Inceptisols (sample No 11) (Table, 2). In general Smectite is considered to have the highest adsorption capacity, but chlorite have low capacities (Shaviv et al., 1985; Sardi and Csitari, 1998).

Table (2): K forms and Semi quantitative distribution of clay minerals in studied soil.

\begin{tabular}{|c|c|c|c|c|c|c|c|c|}
\hline \multirow[b]{2}{*}{ 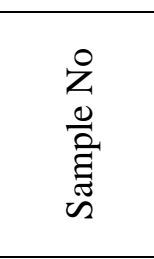 } & \multicolumn{2}{|c|}{$\mathrm{K}$ - forms $\mathrm{cmol}_{\mathrm{c}} \mathrm{kg}^{-1}$} & \multicolumn{6}{|c|}{ Clay Minerals } \\
\hline & 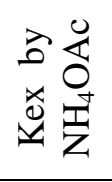 & 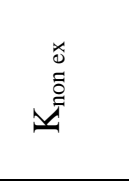 & 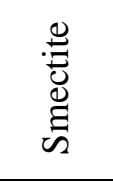 & 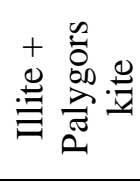 & $\frac{\stackrel{\mathscr{\Xi}}{\frac{0}{c}}}{己}$ & 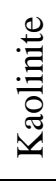 & \begin{tabular}{l}
$:=$ \\
$: \bar{D}$ \\
\hdashline
\end{tabular} & 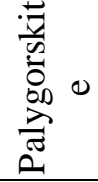 \\
\hline 1 & 1.37 & 3.88 & +++ & +++ & +++ & + & ++ & ++ \\
\hline 2 & 3.22 & 4.10 & +++ & +++ & ++ & + & + & ++ \\
\hline 3 & 0.79 & 0.90 & +++ & +++ & +++ & + & + & ++ \\
\hline 4 & 1.55 & 2.89 & +++ & +++ & +++ & + & + & + \\
\hline 5 & 1.52 & 2.91 & +++ & +++ & +++ & + & + & + \\
\hline 6 & 1.32 & 2.61 & +++ & +++ & +++ & + & + & ++ \\
\hline 7 & 0.82 & 1.15 & ++++ & ++ & ++ & + & - & + \\
\hline 8 & 0.60 & 0.76 & +++ & ++ & +++ & + & + & + \\
\hline 9 & 0.82 & 1.37 & +++ & +++ & +++ & + & + & + \\
\hline 10 & 0.87 & 1.10 & +++ & +++ & +++ & + & + & + \\
\hline 11 & 0.99 & 1.94 & ++ & +++ & +++ & + & + & + \\
\hline 12 & 0.67 & 1.72 & +++ & +++ & +++ & + & + & + \\
\hline 13 & 1.16 & 1.87 & +++ & ++ & +++ & + & - & - \\
\hline 14 & 0.72 & 0.62 & +++ & +++ & +++ & + & + & + \\
\hline 15 & 0.77 & 2.42 & ++++ & ++ & ++ & + & + & ++ \\
\hline 16 & 1.30 & 2.69 & ++++ & +++ & ++ & + & +++ & + \\
\hline Average & 1.16 & 2.06 & & & & & & \\
\hline
\end{tabular}

The adsorption curve (Figure 2) showed an initially, K-adsorption was rapid then it leveled of with time. The initial fast adsorption may be related to the $\mathrm{K}^{+}$ adsorption on the surface sites, similar finding was found by (Al-Obaidi, 1996; Mehmedany, 1999; and Mam Rasul, 2008). 
Mesopotamia J. of Agric.

Vol. (42) NO. (1) 2014
ISSN: 2224-9796 (Online)

ISSN: $1815-316$ X (Print)

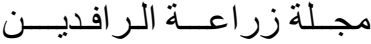
المجلد(42) العدد(1) 2014
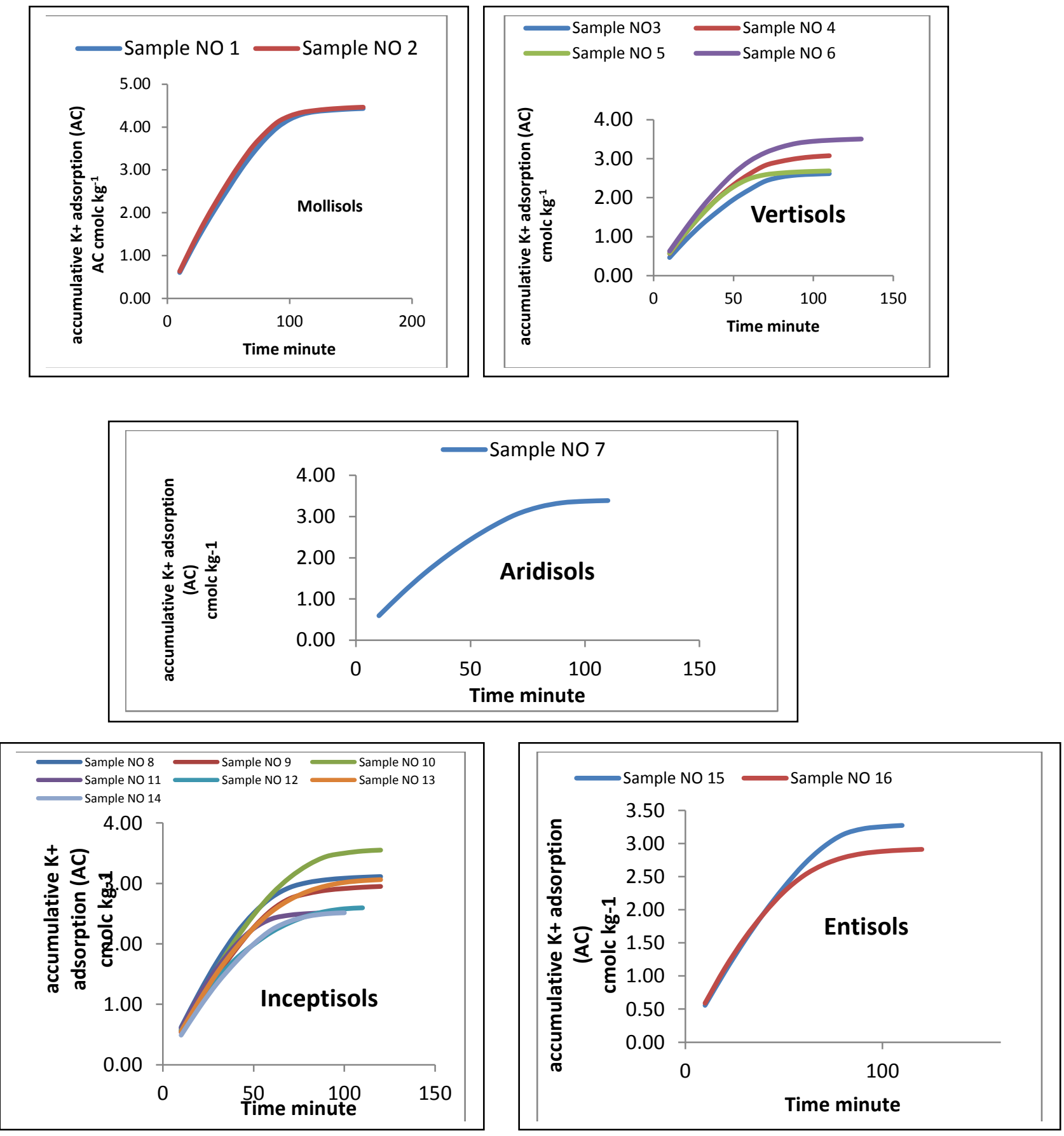

Figure (2): The cumulative $\mathrm{K}^{+}$adsorption for the studied soils by using miscible displacement technique.

Desorption capacity: The data in Figure (3) refers that the soil desorption capacity ranged from 1.11 to $2.67 \mathrm{cmol}_{\mathrm{c}} \mathrm{kg}^{-1}$, the lowest value was recorded in Inceptisols (sample No 11) while the highest value was recorded in Mollisols (sample No 2). The maximum quantity of K-desorption was related to silt fraction in soil. Positive correlation between K-desorption and silt fraction was recorded $\left(\mathrm{r}=0.68^{* *}\right)$. Similar result was observed by Simard et al., (1992) they found that the K-release rate from clay and silt was larger than sand. Or may be due to 
Mesopotamia J. of Agric.

Vol. (42) NO. (1) 2014
ISSN: 2224-9796 (Online)

ISSN: $1815-316 \mathrm{X}$ (Print)

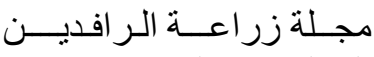

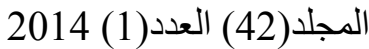

soil mineral structure (Badraoui et al., 1992) they found that the soil content mica, illite and vermiculate minerals have a high release rate of $\mathrm{K}^{+}$compared to Kaolinite minerals.

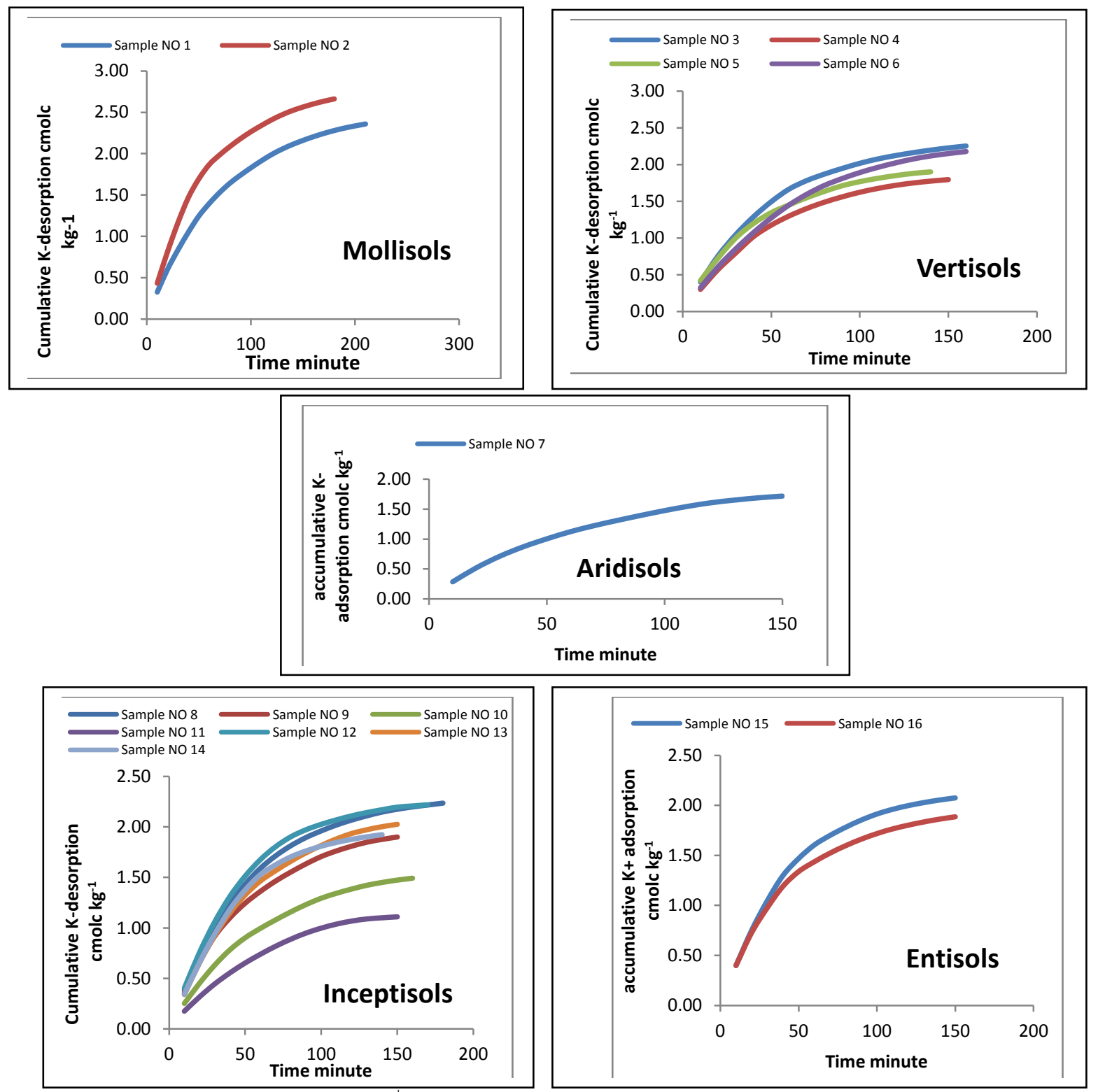

Figure (3): The cumulative $\mathrm{K}^{+}$desorption for studied soil by using miscible displacement technique

Soils are generally more native of $\mathrm{K}^{+}$during desorption than adsorption, this phenomenon called hysteresis. The desorption rate coefficient can be substantially different from that for adsorption. The desorption isotherm indicated a large adsorption-desorption hysteresis among soils that have a high affinity for $\mathrm{K}^{+}$and less hysteresis for soils with less affinity for $\mathrm{K}^{+}$. Strong hysteresis behavior of $\mathrm{K}$ adsorption-desorption was observed for the studied soils as illustrated by the discrepancy between the adsorption and desorption isotherm. Due to strong adsorption and low recovery, the results conclude that potassium is not susceptible to leaching losses from the surface sites. The low value of DI means increase in hysteresis. Table (3) shows the lower DI values which indicate the increase in difficulty of the sorbed $\mathrm{K}^{+}$to desorb from soil surfaces. 
Mesopotamia J. of Agric.

Vol. (42) NO. (1) 2014
ISSN: 2224-9796 (Online)

ISSN: $1815-316 \mathrm{X}$ (Print)

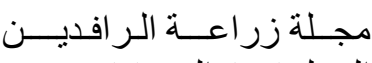

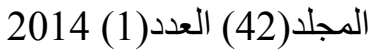

Table (3):The value of rate adsorption coefficient, rate desorption coefficient, and desorption index for the studied soils.

\begin{tabular}{|c|c|c|c|c|c|}
\hline $\begin{array}{l}\text { Sample } \\
\text { No }\end{array}$ & Soil order & $\begin{array}{l}\text { Rate of coefficient } \\
\text { of adsorption } * 10^{-1}\end{array}$ & $\begin{array}{l}\text { Rate of coefficient } \\
\text { of desorption } * 10^{-1}\end{array}$ & $\begin{array}{l}\text { Desorption } \\
\text { Index (DI) }\end{array}$ & Mean DI \\
\hline 1 & Mollisols & 0.25 & 0.12 & 0.48 & \multirow{2}{*}{0.45} \\
\hline 2 & Mollisols & 0.24 & 0.10 & 0.42 & \\
\hline 3 & Vertisols & 0.21 & 0.08 & 0.38 & \multirow{4}{*}{0.47} \\
\hline 4 & Vertisols & 0.24 & 0.10 & 0.42 & \\
\hline 5 & Vertisols & 0.19 & 0.10 & 0.53 & \\
\hline 6 & Vertisols & 0.22 & 0.12 & 0.55 & \\
\hline 7 & Aridisols & 0.28 & 0.11 & 0.40 & 0.40 \\
\hline 8 & Inceptisols & 0.21 & 0.07 & 0.33 & \multirow{7}{*}{0.35} \\
\hline 9 & Inceptisols & 0.21 & 0.08 & 0.38 & \\
\hline 10 & Inceptisols & 0.27 & 0.07 & 0.26 & \\
\hline 11 & Inceptisols & 0.23 & 0.06 & 0.26 & \\
\hline 12 & Inceptisols & 0.19 & 0.07 & 0.37 & \\
\hline 13 & Inceptisols & 0.19 & 0.11 & 0.58 & \\
\hline 14 & Inceptisols & 0.22 & 0.06 & 0.27 & \\
\hline 15 & Entisols & 0.27 & 0.10 & 0.37 & \multirow{3}{*}{0.40} \\
\hline 16 & Entisols & 0.20 & 0.08 & 0.40 & \\
\hline Average & & 0.23 & 0.09 & 0.40 & \\
\hline
\end{tabular}

The highest value of DI for potassium were recorded from sample No (1, 5, 6, and 13), while the moderate values were recorded from samples No $(2,3,4,7,8,12,15$ and 16), finely the lower values were obtained from samples No (10,11, and 14) (Table 3) and (Figure 4).

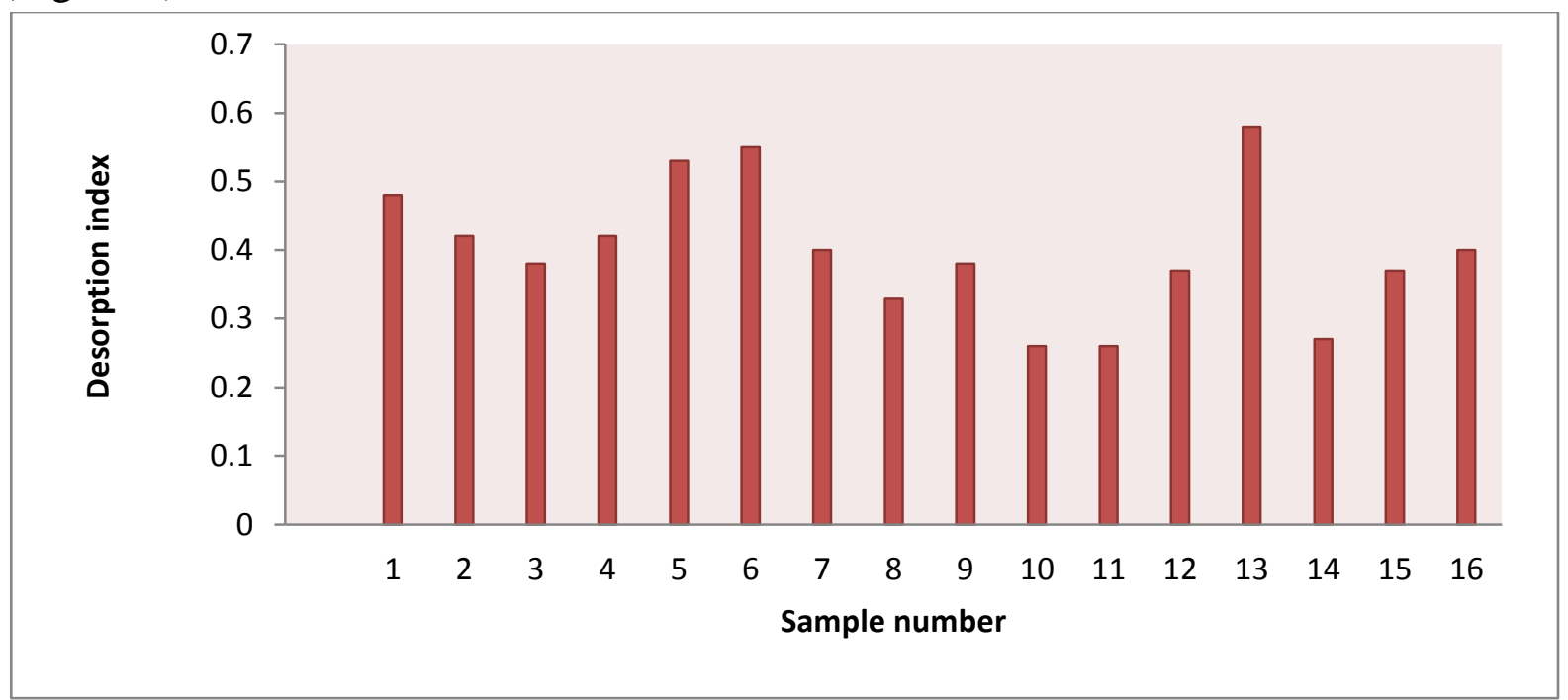

Figure (4): Arrangement of soil desorption index (DI) values.

The mean of DI values are differing among the studied soil (table 3 ) the highly value (0.47) was recorded from Vertisol order while the lowest value (0.35) was recorded from Inceptisol. This may be due to differing in type of clay minerals (table 2). The little amount of $\mathrm{K}^{+}$ adsorption was desorped back into the liquid phase (Figure 5), this indicating to a stronger tendency of $\mathrm{K}^{+}$to be sorbed by clay or organic matter there by these soils have a large specific 
Mesopotamia J. of Agric.

Vol. (42) NO. (1) 2014
ISSN: 2224-9796 (Online)

ISSN: $1815-316 \mathrm{X}$ (Print)

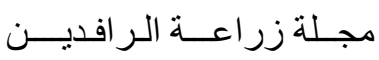

المجلد(42) العدد(1) 2014 ألراعن

surface area (Shaviv et al., 1985; and Sharpley 1987). These results agree with Alobaidi and Hussin (2010) in Ninavia governorates $(0.20-0.90)$ with an average 0.50 .
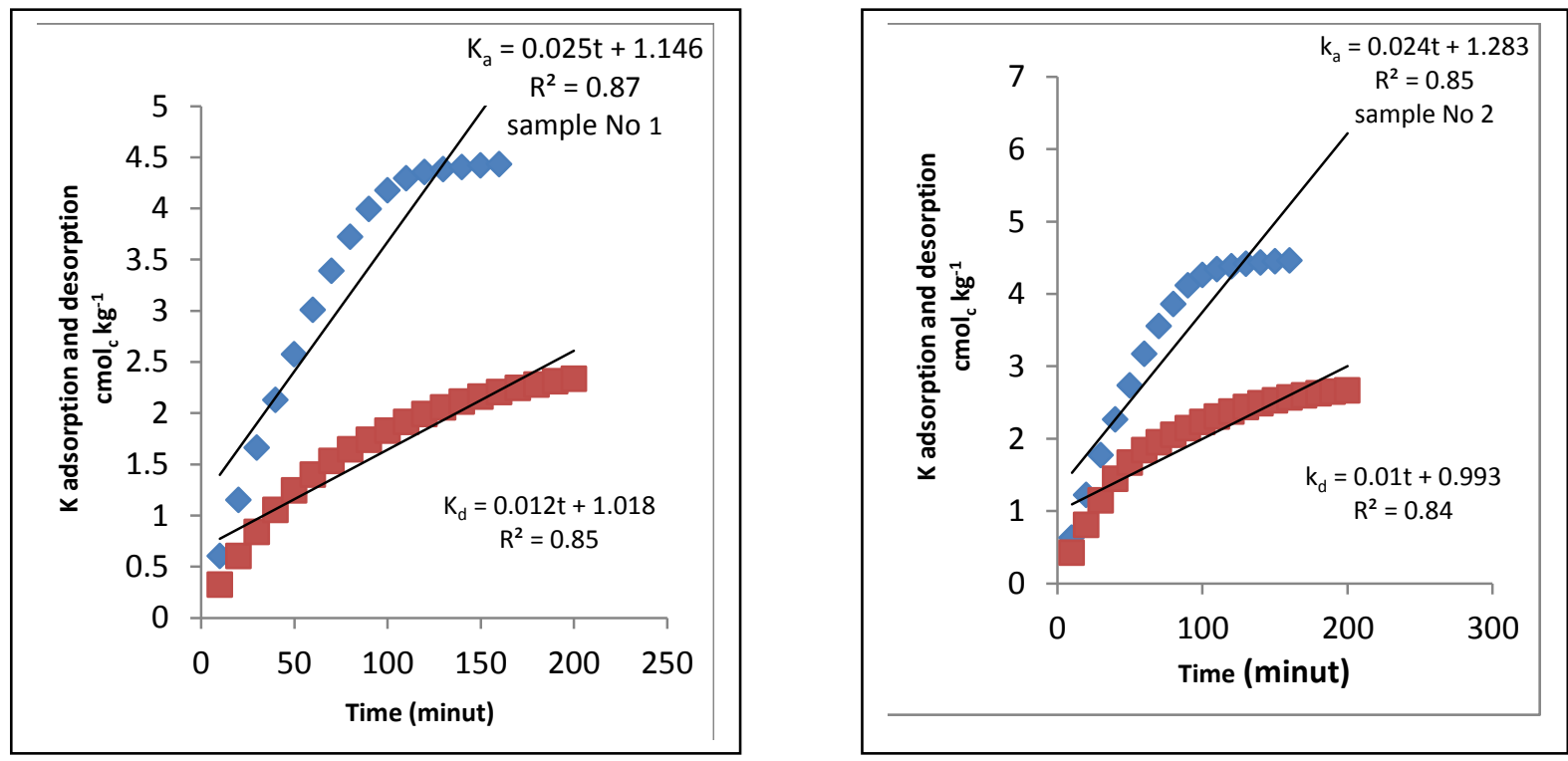

Figure (5): Adsorption and desorption of $\mathrm{K}^{+}$(sample No 1 to No 2) in the studied soils.
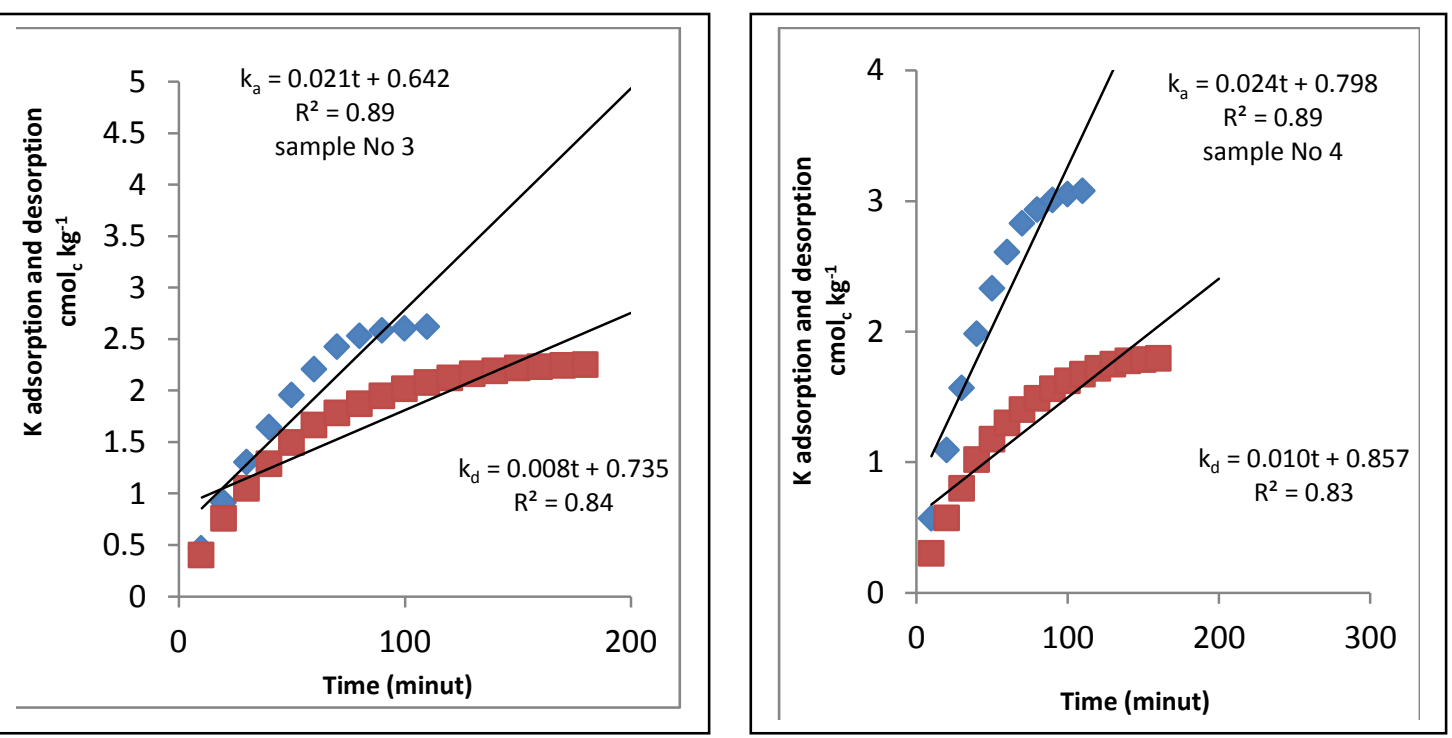
Mesopotamia J. of Agric.

Vol. (42) NO. (1) 2014
ISSN: 2224-9796 (Online) ISSN: 1815-316 X (Print)
مجـلة زراعــة الر افديــن

المجلد(42) العدد(1) 2014
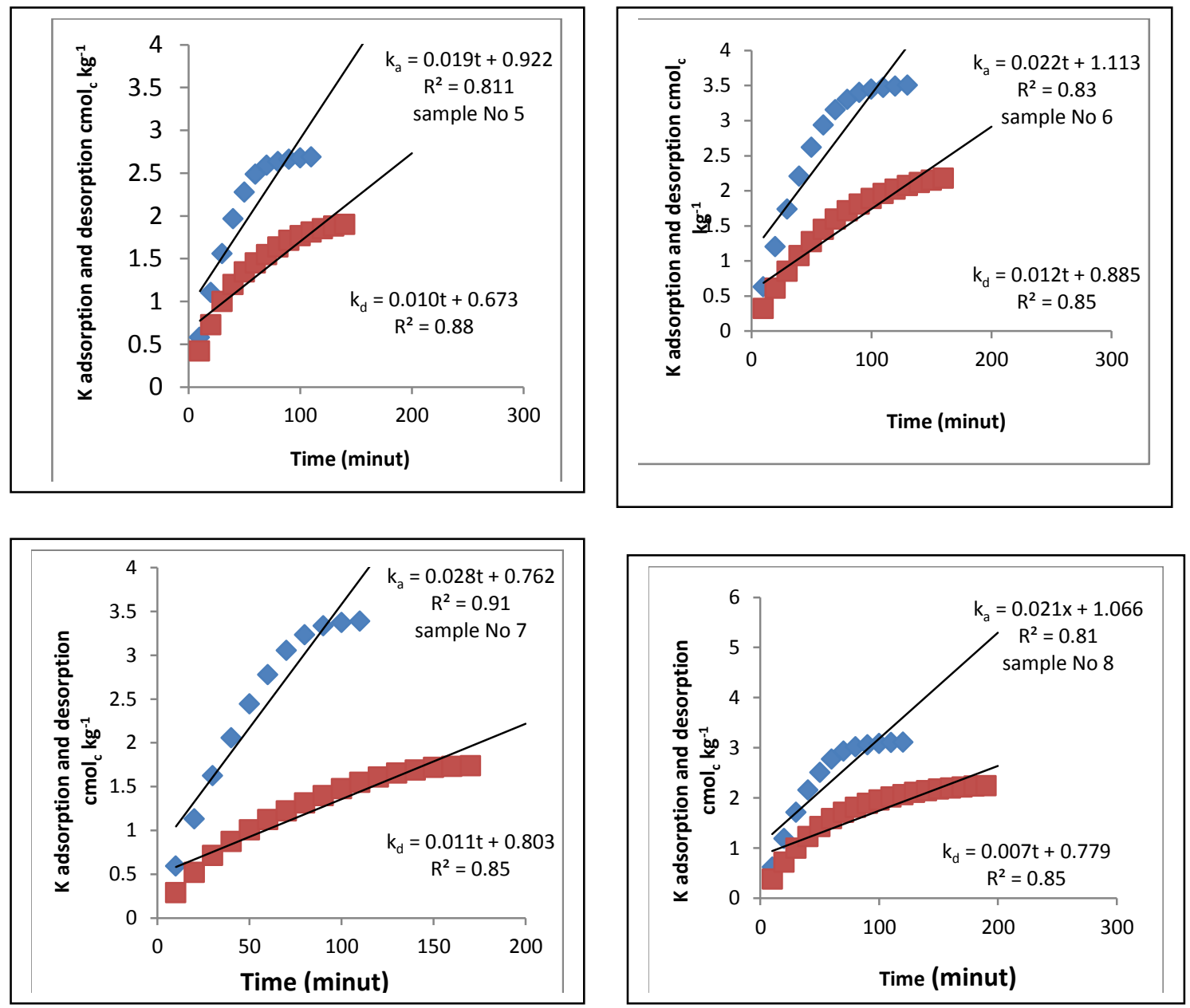

Figure (4): Adsorption and desorption of $\mathrm{K}^{+}$(sample No 3 to No 8) in the studied soils.
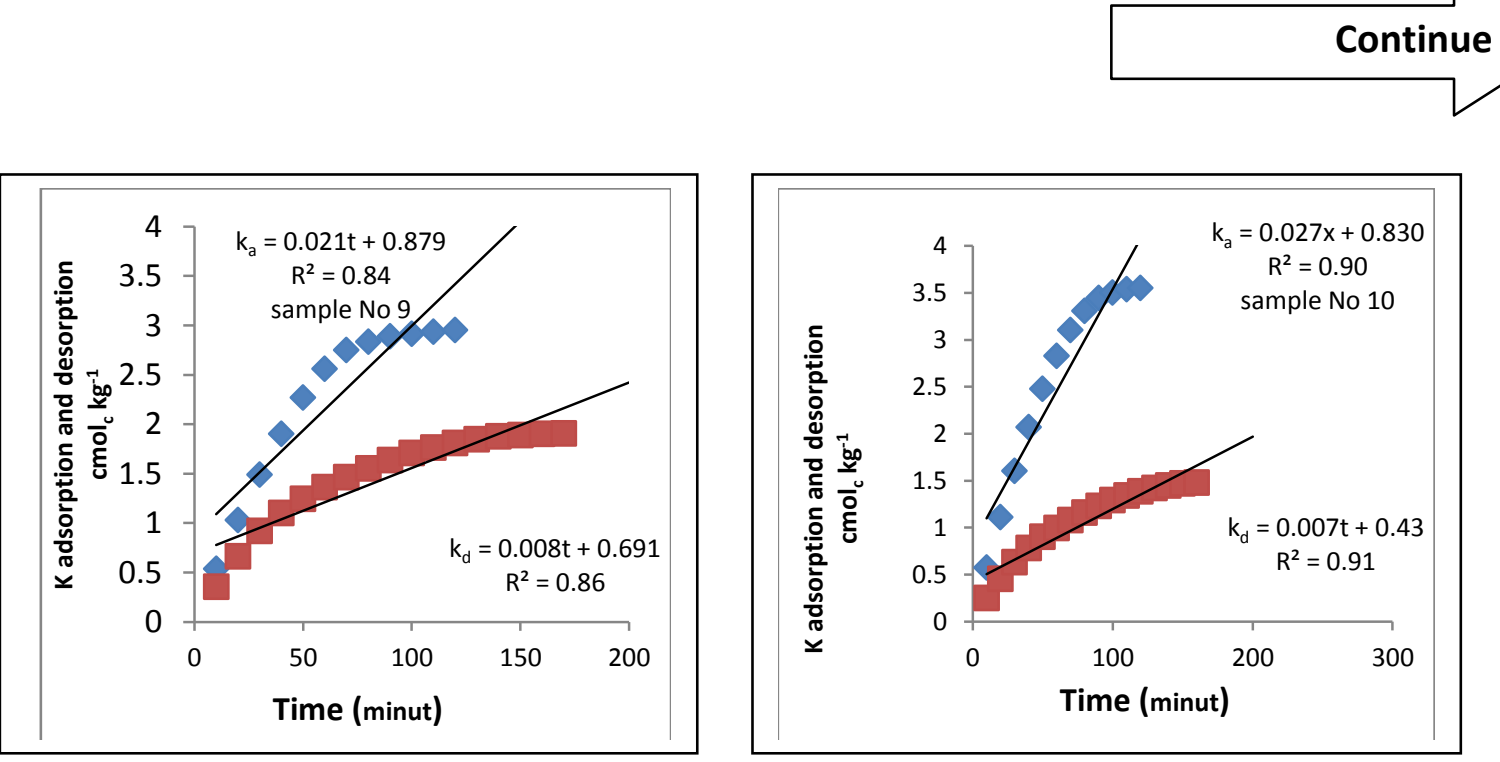
Mesopotamia J. of Agric.

Vol. (42) NO. (1) 2014
ISSN: 2224-9796 (Online) ISSN: 1815-316 X (Print)
مجـلة زراعــة الر افديــن

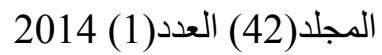
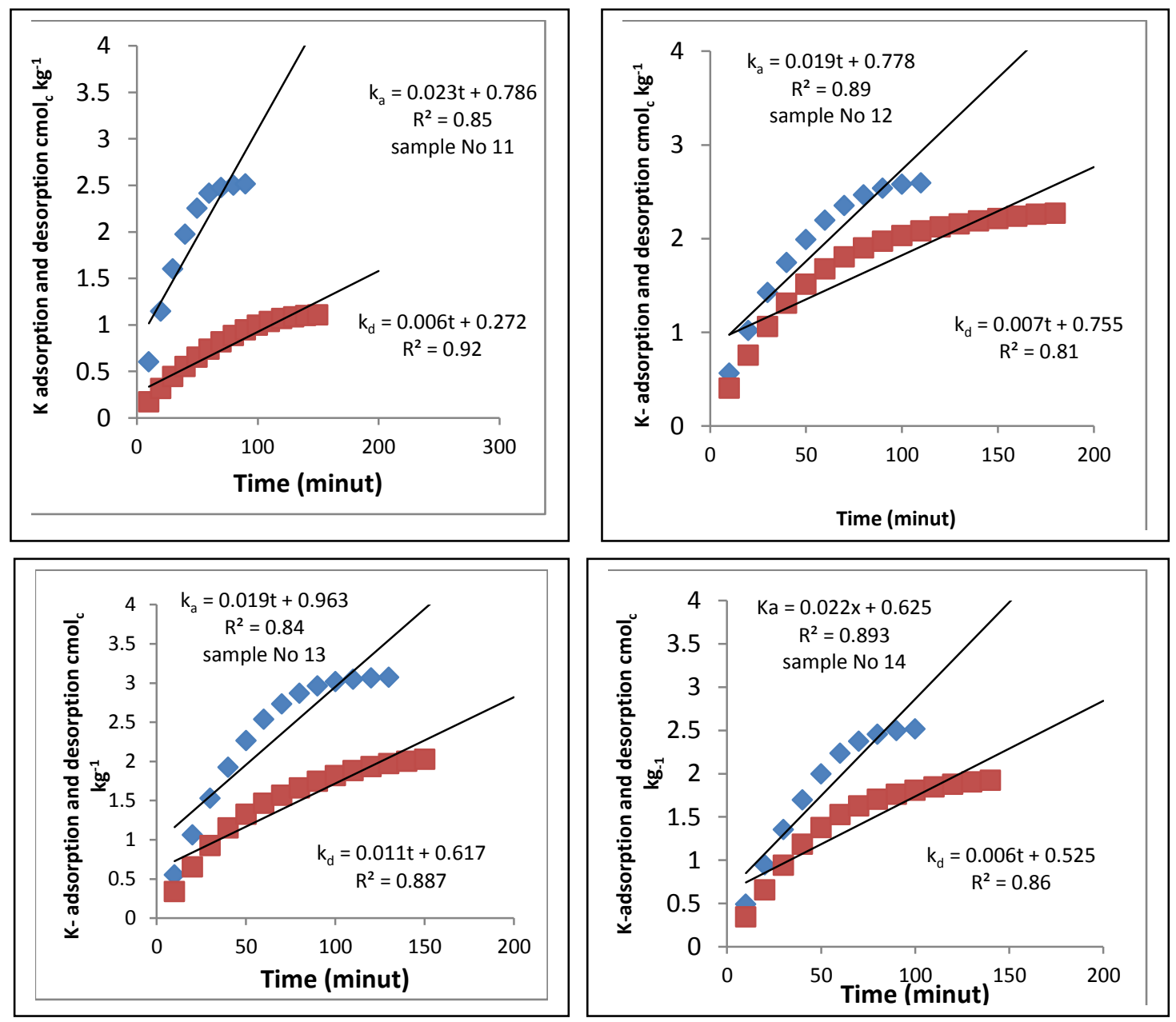

Figure (4): Adsorption and desorption of $\mathrm{K}^{+}$in the studied soils (sample No 9 to 14).
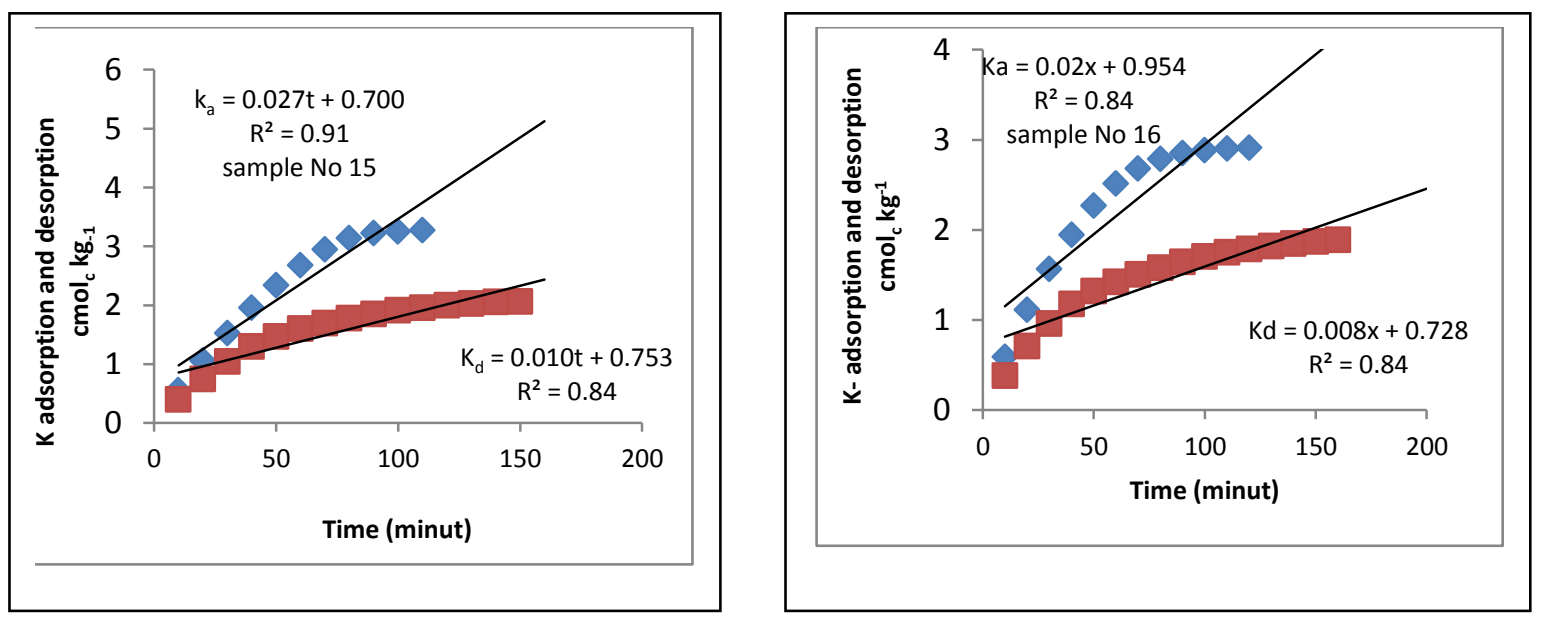

Figure (4): Adsorption and desorption of $\mathrm{K}^{+}$in the studied soils (sample No 15 to 16). 


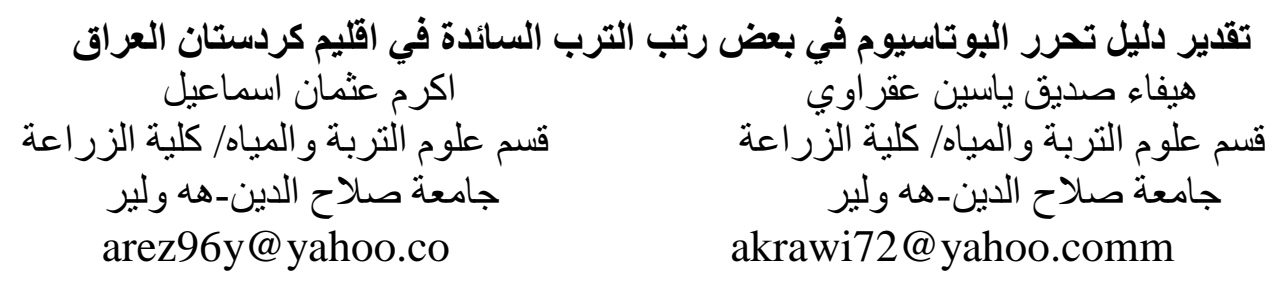

الخلاصة

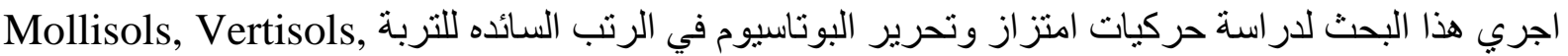
Aridisols, Inceptisols, Entisols

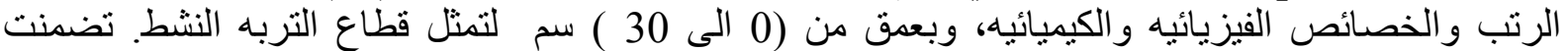

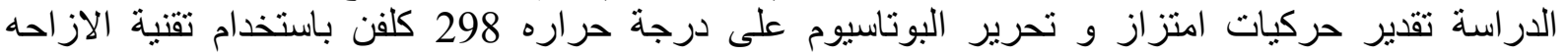
الامتزاجيه الهادئة miscible displacement technique وباستخدام

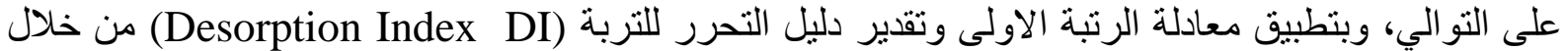

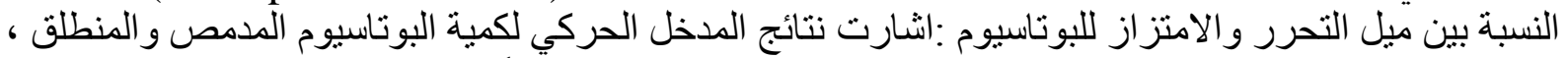

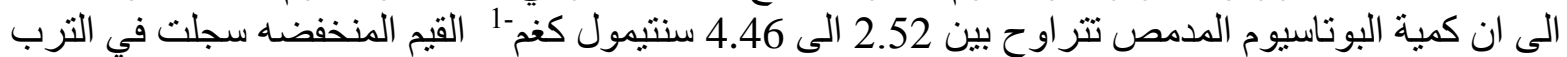
Inceptisols

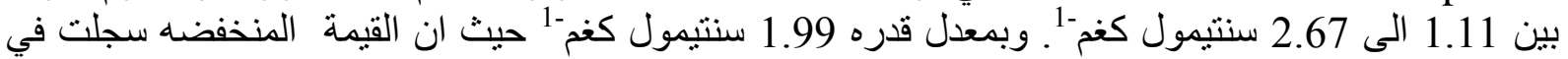

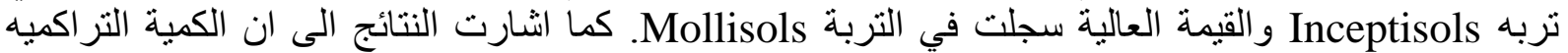

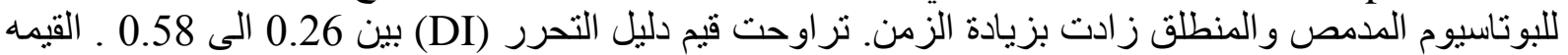

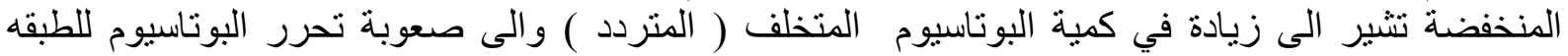

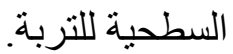

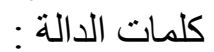

تاريخ تسلم البحث 2012 / 2012 وقبوله 9/10 / 2012

\section{REFERENCE}

Al-Obaidi, M. A., (1996). Kinetic of Potassium in Some Iraqi Soil. Ph D. Thesis. College of Agriculture, University of Baghdad, Iraq. (In Arabic).

Al-Obaidi, M. A., and A. S. Hussin,(2010). Kinetic of K-adsorption and desorption in some Nineveh government. Mesopotamia Journal of Agriculture.38 (4): 50-59.

Al-Zubaidi, A., (2003). The status of potassium in Iraqi soils. Pp 129-142. Proceedings Of The Regional Workshop: "Potassium and Water Management In West Apia and North Africa". In A. E. Johnston (ed.). International Potash Institute IPI.

Badraoui, M., M. Agbam, A. Merzouk, P. R. Bloom, R. Bouabid, B. Soudi, A. Mimouni, and B. Bouchaora, (1992). Chemistry and mineralogy potassium. Fertilizer use efficiency under rain. Fed. Agric. In W. A and N. A. Proceeding Of The Fourth Regional Workshop 5- 10. May 1991. Agadir, Morocco ICARDA, 1992.

Conti, M. E., A. M. De La Horra, D. Effron, and D. Zourarakis. (2001). Factors affecting potassium fixation in Argentine agricultural soils. Journal of Soil Science. and Plant Analysis. 32:2679-2690.

Cox, A. E., and B. C. Joern, (1997). Release Kinetic of non-exchangeable potassium by sodium tetraphenylboron in Midwestern soils. Journal of Soil Scicence. 162:588598. 
Dhaliwal, A. K., R. K. Gupta, Yadvinder-Singh, and Bijaw-Singh (2006). Potassium fixation and release characteristics of some benchmark soil series under RiceWheat cropping system in the Indo-Gangetic plains of northwestern India. Commun. Journal of Soil Science and Plant Analyses. 37:827-845.

Gardiner, W. C. J., (1969). Rates and Mechanisms Of Chemical Reaction. Benjamin, New York.

Goli-Kalanpa, E., M. H. Roozitalab, and M. J. Malakouti, (2008). Potassium availability as related to clay mineralogy and rates of potassium application. Journal of Soil Science. and plant Analysis. 39:2721-2733.

Goulding, K. W.,(1984). The availability of potassium in soils to crop as measured by its release to calcium-saturated cation exchange with resin. Journal of Agriculture Science Camb. 103:263-275.

Hesse, P.R. (1971). A Text Book Of Soil Chemical Analysis William Clowes and Sons. Limited, London, Beccles and Clolchester.

Jackson, M. L. (1973). Soil Chemistry Analysis. Prentice Hall, Inc. London.

Klute, A., (1986). Methods Of Soil Analysis. Part (1) $2^{\text {nd }}$ Monograph. No (9) Agronomy. Kozhekov, O. K., and N. A. Yakovleva. (1977). Determination of carbonate and carbonate mineral in soils. Journal of Soviet Soil Science. 9:620-622.

Mam-Rasul, Gh. A., (2008). Physic-Chemical Behavior of Potassium in Predomination Soil Orders of Sulaimani Governorate. PhD. Thesis College of Agriculture, Sulaimani University, Iraq.

Marazadori, C., A. I. Vittori, C. Ciavatta, and P. Sequi, (1991). Soil organic matter influence on adsorption and desorption of boron. Journal of Soil Science Society of American. . 55:1582-1585

Martin, H. W., and D. L. Sparks (1983). Kinetics of nonexchangeable potassium release from two Coastal plain soils. Journal of Soil Science Society of American. 47:883-887.

Mehmedany, L. A., (1999). Potassium Hpysico-Chemical Behavior For Some Calcareouse Soils In Iraqi- Kurdistan region. M.Sc. Thesis, College of Agriculture. Dohuk University, Iraq.

Page, A. L., R. H. Miller and D. R. Kenney (1982). Methods Of Soil Analysis. Part2. America. Society. Agriculture. Public. Madison, Wisconsin. U S A.

Pratt, P. F., (1982). Potassium. ln: Methods Of Soil Analysis. Part 2. C.F. Page, et al., 1982.

Richards, L. A., (1954). Diagnosis and Improvement Of Saline and Alkali Soils. Agriculture. Hand book NO 60, USDA Washington.

Rowell, D. L., (1996). Soil Science. Methods and application. University. of Reading. UK.

Sardi, K., G. Csitari, (1998). Potassium fixation of different soil types and nutrient levels. Journal of. Soil Science. and Plant Analysis, 29:1843-1850. 
Sharpley, A. N. (1987). The kinetic of potassium desorption. Journal of Soil Science Society of American. 51:912-917.

Shaviv, A., P. E. Mohsin, E. Part, and S. V. Mattigod, (1985). Potassium fixation characteristic of five southern California soils. Journal of Soil Science Society of America 49:1105-1109.

Simard, R. R., C. R. Dekimpe and J. Zizka, (1992). Release of potassium and magnesium from soil fraction and its kinetics. Journal of Soil Science Society of America. 56:1421-1428.

Soil Survey, (1999). Soil Taxonomy: A Basic System Of Soil Classification For Making and Interpreting Soil Survey. USDA-NRCS. Agric. Handbook No.436.U. S. Government printing Office. 870.

Sparks, D.L. 2000. Bioavailability of soil potassium, pp. D-38-D-52. In M.E. Sumner (ed.) Handbook Of Soil Science, CRC Press, Boca Raton, FL.

Sparks, D. L., J. E. Rechcigl, (1982). Comparison of batch and miscible displacement techniques to describe potassium adsorption kinetics in Delaware Journal of Soil Science Society of America. 46:875-877.

Sparks, D. L., L. W. Zelanzy, and D. C. Martents, (1980). Kinatics of potassium desorption in soil using miscible displacement. Journal of Soil Science Society of America. 44:1205-1208.

Wada, K., and Y. Kakuto. (1993). Non - exchangeable potassium in a manometer mineral, and mica in Korean ultisol. Journal of Soil Science Society of America. 57:552-555. 